\title{
PEMBERDAYAAN KELOMPOK MASYARAKAT SEBAGAI PENGAWAS MINUM OBAT PASIEN GAGAL GINJAL KRONIS DI RS SANJIWANI
}

\author{
DGA Budiyasa $^{1,2}$, DM Sadguna $^{1,2}$, DAP Niti Widari ${ }^{3}$, Sri Masyeni $^{1,2}$ \\ ${ }^{1}$ Departemen Ilmu Penyakit Dalam RS Sanjiwani Gianyar \\ ${ }^{2}$ Fakultas Kedokteran dan Ilmu Kesehatan, Universitas Warmadewa \\ ${ }^{3}$ Fakultas Ekonomi Universitas Warmadewa
}

\begin{abstract}
Abstrak
Penyakit ginjal kronis (PGK) merupakan penyakit yang ditandai penurunan fungsi ginjal yang semakin progresif sehingga memerlukan bantuan berupa terapi pengganti mesin dialysis untuk menggantikan fungsi ginjal. Hemodialisis dengan mesin hemodialisis harus dilakukan secara rutin 2-3 kali seminggu dan berkesinambungan seumur hidup pasien. Selain hemodialisis atau cuci darah rutin, pasien PGK juga harus mengonsumsi obat dalam jumlah yang relatif banyak yang apabila tidak dikonsumsi secara rutin akan memicu kondisi akut yang mungkin akan memperburuk fungsi ginjal. Untuk mengantisipasi hal ini diperlukan bantuan keluarga terdekat untuk membantu mengawai pasien PGK untuk selalu mengonsumsi obat-obat sesuai dengan instruksi dokter. Kegiatan PKM ini bertujuan untuk membentuk kelompok Kader Siaga Minum Obat pada mitra yang akan memantau pasien mematuhi instruksi dokter. Kegiatan PKM dimulai dengan sosialisasi kegiatan, focus group discussion, pelaksanaan kegiatan serta evaluasi hasil kegiatan. Adapun outcome dari PKM ini adalah terdapat peningkatan pengetahuan mitra mengenai penyakit PGK, pencegahan perburukan serta peningkatan kualitas hidup pasien PGK sebesar $81 \%$ pada delapan mitra PKM. Output sementara, kegiatan dilakukan dengan observasi dan pengamatan frekuensi kejadian perburukan penyakit pada pasien sebagai hasil/peran dari fungsi kader Siaga Minum Obat.
\end{abstract}

Kata kunci: pemberdayaan, PGK, Kader Siaga

\section{Pendahuluan}

Penyakit Ginjal Kronik (PGK) masih menjadi masalah di Indonesia dengan prevalensi kasus yang terus meningkat mencapai 200-250/1 juta penduduk. ${ }^{1}$ Berdasarkan data dari Indonesian Renal Registry tahun 2015, jumlah pasien PGK yang memerlukan hemodialisis adalah 18.613 orang. Survei oleh Perhimpunan Nefrologi Indonesia (Pernefri) di Jakarta, Yogyakarta, Surabaya, dan Bali pada tahun 2009 mendapatkan prevalensi PGK 12,5\% dengan kriteria estimasi laju filtrasi glomerulus (eLFG) $<60 \mathrm{ml} /$ menit $/ 1,73 \mathrm{~m}$ menurut formula Cockroft-Gault adjusted for body surface area 
(CG-BSA). ${ }^{2}$ Penyakit ginjal kronik stadium awal sering tidak terdiagnosis, sementara PGK stadium akhir yang disebut juga gagal ginjal memerlukan biaya perawatan dan penanganan yang sangat tinggi untuk hemodialisis atau transplantasi ginjal. Penyakit ini baik pada stadium awal maupun akhir memerlukan perhatian. Penyakit ginjal kronik juga merupakan faktor risiko penyakit kardiovaskuler. ${ }^{3}$ Kematian pada PGK dapat akibat penyakit non-kardiovaskular atau kardiovaskular. ${ }^{4}$ Gejala PGK adalah sesak nafas, bengkak pada seluruh tubuh, anemia serta hipertensi.

Penyakit ini ditandai dengan penurunan fungsi ginjal yang semakin progresif, dengan pengobatan definitif adalah transplantasi ginjal yang masih jarang dapat dikerjakan terkait teknis yang sulit, biaya tinggi serta kesulitan mencari donor ginjal yang sangat langka, dan ada risiko akan terjadi penolakan terhadap ginjal yang ditransplantasikan. Oleh karena sampai saat ini tata laksanan PGK adalah menjaga fungsi ginjal dengan mesin dialysis yang akan membuang sisa metabolisme sehingga tidak terjadi gejala serta mampu menjaga kelangsungan hidup pasien. Proses hemodialisis dilakukan 2-3 kali dalam seminggu, untuk tetap menjaga keseimbangan cairan dalam tubuh pasien. Selain dialysis/cuci darah penderita masih harus mengonsumsi obata-obatan dalam jumlah yang relatif banyak, tidak terkadang berjumlah lebih dari 5 jenis obat setiap hari. Hal ini tentu akan memicu rasa jenuh pada pasien sehingga beberapa dari pasien PGK memerluka hemodialisis ekstra karena tidak mengonsumsi obat. Oleh karena itu adalah sangat penting untuk selalu mengingatkan pasien PGK untuk minum obat secara teratur untuk mengurangi kebutuhan dialysis.

\section{Masalah, solusi pemecahan masalah mitra dan pelaksanaan PKM}

Dari observasi dan wawancara yang dilakukan pada pasien PGK terungkap bahwa tidak memiliki pengawas atau pemantau minum obat yang akan mengingatkan mereka untuk minum obat apalagi jumlah obat yang harus dikonsumsi berjumlah relatif banyak. Karena itu beberapa pasien membutuhkan dialysis ekstra diluar jadwal yang sudh diprogramkan oleh dokter. Pemberdayaan masyarakat dalam hal ini anggota keluarga yang terdekat dapat dijadikan sebagai Kader Siaga Minum obat yang akan mengawasi pasien PGK di rumah. Tetapi pada kelompok mitra tersebut ditemukan beberapa permasalahan yaitu tidak mengerti secara detil penyakit PGK, bagaimana cara mengurangi kebutuhan dialysis ekstra, belum pernah mendapatkan pengarahan mengenai faktor-faktor pencetus perburukan PGK. Permasalahan lain yang ada pada mitra adalah banyak terjangkit penyakit yang saat ini sedang pandemi yaitu COVID-19, belum ada kelompok-kelompok masyarakat lini terdepan mendapatkan pelatihan-pelatihan mengenai kanker serta upaya pengenalan dini penyakit kanker seperti kanker payudara atapun kanker leher rahim, pendapatan yang tidak menurun akibat pandemi, penunggu pasien tidak 
mengerti membuat pembukuan neraca keuangan usaha keluarga yang baik.

Berdasarkan data permasalahan pada mitra tersebut diatas, program PKM akan memberikan solusi berupa, pemberdayaan masyarakat dengan membentuk Kader Siaga Minum Obat pada kelompok penunggu pasien PGK di RS Sanjiwani, memberikan penyuluhan dan pelatihan serta pendampingan mengenai penyakit PGK, mengawasi pasien PGK untuk selalu minum obat secara rutin serta memberikan pelatihan manajemen keuangan keluarga serta membuat neraca pembukuan keuangan.

Kegiatan PKM diawali dengan sosialisasi kegiatan, focus group discussion untuk identifikasi masalah mitra dan solusi pemecahan, pelaksanaan kegiatan PKM serta evaluasi kegiatan. Kegiatan PKM diawali dengan pre-test untuk mengetahui pengetahuan mitra mengenai penyakit dan kontrol terhadap PGK, kemudian diikuti dengan penyuluhan menggunakan pamphlet, poster, pemutaran video edukasi serta peragaan obat-obat yang dikonsumsi pasien PGK. Materi penyuluhan berupa pemahaman penyakit PGK, dari penyebab, faktor risiko, gejala dan tanda, tata laksana, serta kontrol terhadap jumlah cairan yang bisa dikonsumsi oleh pasien PGK. Tanya jawab interaktif dilakukan pada akhir sesi penyuluhan. Selain materi penaykit PGK, sesuai masalah pada mitra juga dilaksanakan pelatihan mengenai manajemen keuangan, pembutan neraca pembukuan usaha keluarga yang dimiliki oleh mitra.Mengingat pada saat ini situasi pandemi COVID-19 masih terjadi, mitra diberikan alat pelindung diri berupa masker dan hand sanitizer serta souvenir. Pada akhir sesi dilaksanakan post-test untuk mengukur penyerapan materi yang diberikan. Evaluasi terhadap outcome dan output juga dilaksanakan untu menilai keberhasilan program.

\section{Hasil kegiatan}

Jumlah mitra yang terlibat pada kegiatan PKM adalah sebanyak 8 orang mitra yang merupakan pengantar dan penunggu pasien PGK yang menjalani hemodialisis rutin di RS Sanjiwani Gianyar. Kegiatan dilaksanakan pada tanggal 28 Juni 2021 di Ruang Pertemuan poliklinis RS Sanjiwani Gianyar. Setelah sebelumnya dilakukan rapat koordinasi bersama antara pengusul PKM dengan mitra beserta dua orang mahasiswa Fakultas Kedokteran dan Ilmu Kesehatan Universitas Warmadewa. Dari hasil pre-test dan post-tes seperti pada tabel 1, didapatkan peningkatan pengetahuan mengenai penyakit PGK pada mitra dengan peningkatan rerata sekitar $81 \%$. 
https://ejournal.warmadewa.ac.id/index.php/wicaksana

Tabel 1. Hasil evaluasi/outcome peningkatan pengetahuan mitra

\begin{tabular}{cccccc}
\hline \multirow{2}{*}{ No } & Kader & \multicolumn{2}{c}{ Nilai } & Peningkatan (f) & Peningkatan (\%) \\
\cline { 3 - 4 } & & Pre Test & Post Test & & \\
\hline 1 & Mitra 1 & 30 & 90 & 60 & 80 \\
2 & Mitra 2 & 50 & 90 & 40 & 80 \\
3 & Mitra 3 & 40 & 80 & 40 & 100 \\
4 & Mitra 4 & 50 & 90 & 40 & 80 \\
5 & Mitra 5 & 50 & 100 & 50 & 100 \\
6 & Mitra 6 & 50 & 90 & 40 & 80 \\
7 & Mitra 7 & 50 & 80 & 30 & 60 \\
8 & Mitra 8 & 60 & 90 & 30 & 50 \\
\hline
\end{tabular}

Evaluasi keberhasilan program akan diukur dari kepatuhan pasien minum obat serta menurunnya kebutuhan ekstra hemodialisis pada pasien PGK dan meningkatnya kualitas

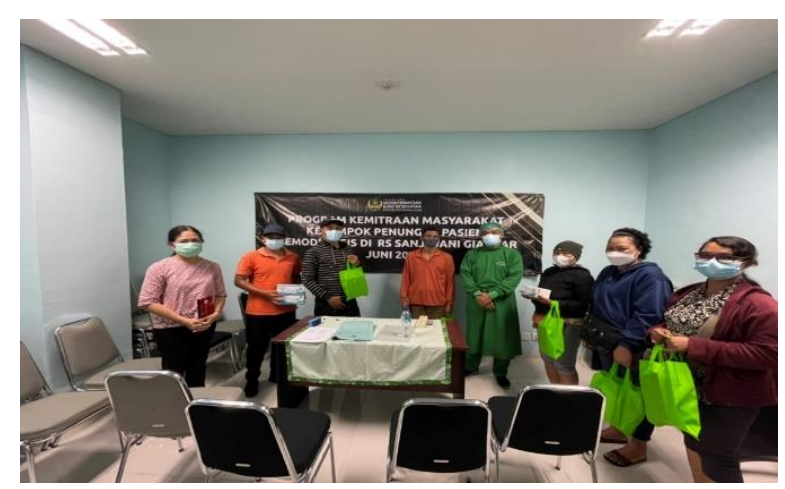

hidup pasien PGK. Kegiatan evaluasi dilakukan dari observasi dan wawancara pada pasien PGK diserati bukti foto kegiatan mitra.

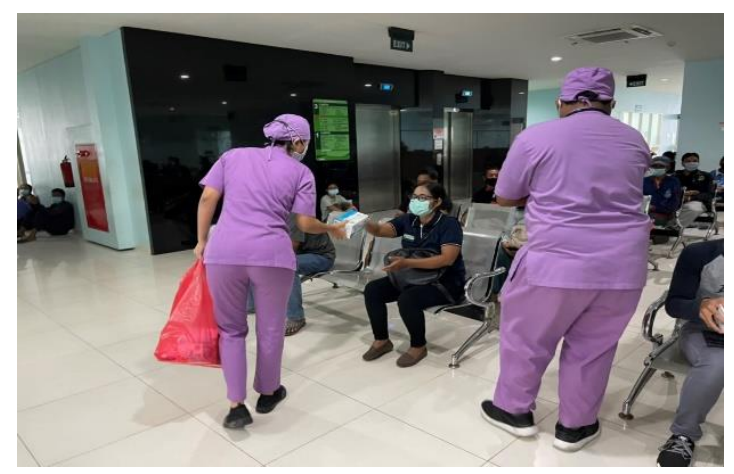



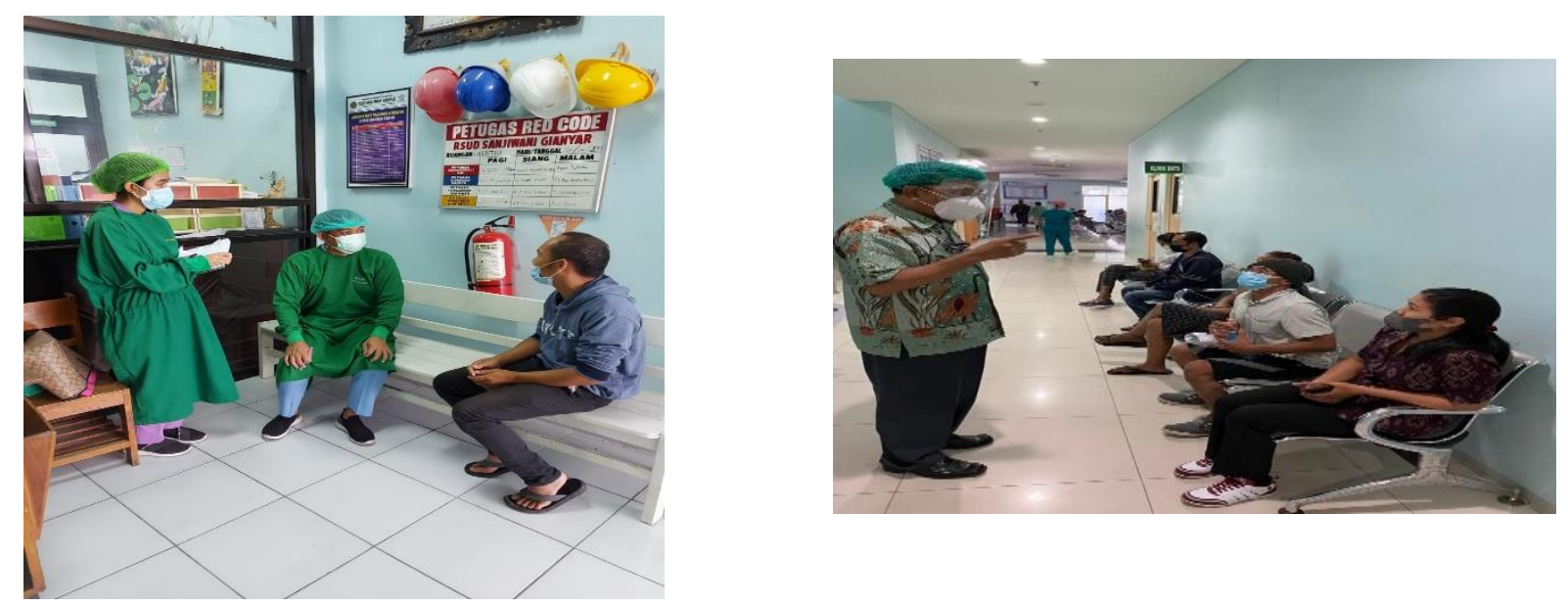

Gambar 1. Foto kegiatan dan evaluasi PKM

\section{Kesimpulan dan saran}

Kegiatan PKM telah memberikan peningkatan pengetahuan mitra mengenai penyakit PGK, kontrol dan pengelolaan pasien PGK.

\section{Saran}

Kegiatan bisa dilanjutkan dalam jangka waktu yang lebih panjang untuk melihat dampak jangka panjang kegiatan. Kegiatan serupa bisa dilaksanakan pada penanganan penyait kronis lainnya dalam membantu program pemerintah meningktakan kualitas hidup pasien PGK.

\section{Ucapan terimakasih}

Terimakasih kepada Fakultas Kedokteran dan Ilmu Kesehatan Universitas Warmadewa yang telah mendanai kegiatan PKM. terimakasih kepada tim PKM, dan mitra yang telah bekerja sama untuk kesuksesan kegiatan PKM ini. 